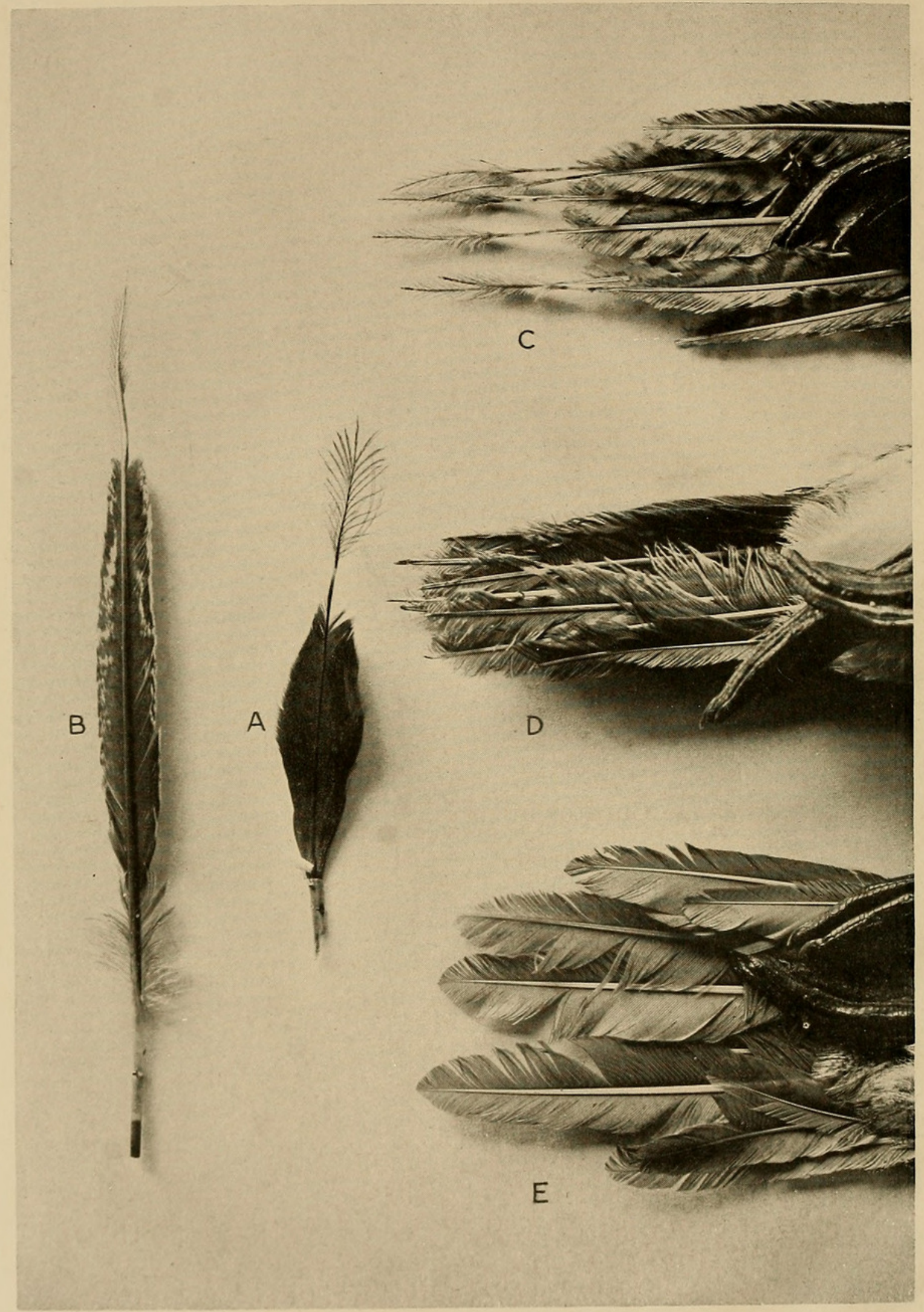

Fig. 98. TAIL-FEATHERS OF DUCKS.

A, Juvenile central rectrice of Wood Duck with down attached; B and C, Juvenile tailfeathers of Torrent Duck with down attached; D, idem, with down recently lost;

E, Post-juvenile tail-feathers of Torrent Duck. 


\title{
SPECIALIZATION OF TAIL DOWN IN CERTAIN DUCKS
}

\author{
By C. William Beebe, Curator of Birds, and
}

L. S. CRANDAll, Assistant Curator.

The careful examination of the birds which are constantly added to the collection of the New York Zoological Park is made for a two-fold purpose. First, of ascertaining their physical condition, freedom from disease and their general health, and second, to obtain data in regard to the characters revealed by the living bird, especially as to the plumage; its moult, structure, pattern and color in continuance of the experiments which have been conducted in the Department of Birds in the past. Unexpected and interesting conditions are occasionally observed, worthy of record, but not dealing directly with the evolutionary problems which the Curator at present has under consideration.

On examining several chicks of the American Wood Duck, Aix sponsa (Linnæus) hatched in the Zoological Park on July 12,1912 , it was noted that the down or plumaceous feathers representing the rectrices at birth, were remarkably stiff and long in comparison to the other feathers of this plumage. The left central rectrice down was measured and found to be $29 \mathrm{~mm}$. in length. Careful watch was kept of a young bird selected for experiment but it was not until July 22, the tenth day after hatching, that an increase in length was noted. On this day, the feather mentioned above had reached a length of $32.5 \mathrm{~mm}$. It soon became evident that this gain in length was due to the pushing out of the rectrices of the juvenile plumage, carrying the plumaceous down on their tips. This left central rectrice, together with its burden of down, was measured carefully every other day for a period of a week, the growth being as follows: 
July $12-29.0 \mathrm{~mm}$. One day chick.

July $22-32.5 \mathrm{~mm}$.

July $23-35.3 \mathrm{~mm}$.

July $25-40.9 \mathrm{~mm}$.

July $27-46.2 \mathrm{~mm}$.

July $29-51.5 \mathrm{~mm}$. Seventeen day chick.

The average daily growth of the feather through the later period is thus shown to have been $2.8 \mathrm{~mm}$. The feather continued to grow at approximately the same rate until August 7th, when the distal down portion was lost. The right central rectrice, to which the down was still attached (Fig. 98, A), on this day measured $74.5 \mathrm{~mm}$. By August 12th, all but two of the remaining tips-the right central and the next to the outer right -had been lost. On August 13th, having persisted for a period of thirty-two days, these last two disappeared, leaving the young bird with the pennaceous juvenile tail feathers remarkably long for an Anserine bird of its age, and with the tips of the feathers not soft and pliable, but exceedingly stiff, the rhachis in each feather showing a reduction in diameter only toward the tip, which was broken squarely off.

Although as has been stated, an increase in the length of the rectrices was noted on the tenth day after hatching, it was not until July 26, four days later, that incipient growth of the under tail-coverts and the feathers of the pectoral tracts was observed. These were the first of the contour feathers to appear, the upper tail-coverts and lower back feathers being delaved for another three days, so that the rectrices had begun their growth a full week before the other important pterylæ of contour feathers. These latter carried the plumaceous feathers on their tips for a very short period, the attachment being extremely weak and they were lost almost at once, as is the case with the majority of birds.

The interesting point about all this, is the impetus in growth of the juvenile rectrices, hinting of some function in early life of which we are still ignorant, and the alteration in structure of the rhachis of the juvenile rectrices, due to the extremely intimate relation which exists between these feathers and the preceding natal down. 
In the Ruddy Duck, Erismatura jamaicensis (Gmel.), the retention of the caudal down is carried a stage further, the stiffened shafts of the nestling plumage often remaining in place until most of the scanty, soft barbs have worn away. Not until the juvenile rectrices are three-fourths grown, does the down begin to lose its hold and fall. The bare, truncated extremities of the juvenile tail-feathers give the tail, as a whole, an appearance very unlike that of the succeeding moult, where the rectrics, though stiff as those of a woodpecker, yet taper at the tip and end in finely graduated points.

In examining, at the American Museum, a series of Torrent Ducks, Merganetta columbiana Des Murs, from Colombia, South America, I was at once struck by the condition of the rectrices in two young males. They were shot on the 25th of September and had attained the full juvenile plumage. In fact, the long scapulars and the tail-feathers already showed considerable wear. The latter were the special point of interest, carrying the specialization of the rectrice down to an extreme, far beyond that in the two stages already described in the Wood and Ruddy Ducks. The general effect was of a stiff-vaned. distal, feather racket connected with the normal part of the rectrice by a considerable extent of strong, bare shaft (Fig. 98, B and C). It seemed impossible at first glance that the stiffened tips had anything in common with the down plumage of other ducks.

The first close examination showed, however, that these peculiar tips were the persistent down plumage, much abraded, but still remaining attached to the full-grown and already considerably worn tail-feathers of the succeeding plumage. Two facts were self evident; first, that in Merganetta even in the down plumage, tail-feathers, specialized in the direction of the stiffened adult rectrices are present and must be of considerable use in enabling the young birds to avoid being carried down stream in a rush of water, or in helping them to clamor up slippery, mossy rocks; second, the physical connection between these down feathers and the succeeding juvenile rectrices is so strong that the former persist long after the next plumage is full grown, and during this period are of material benefit in providing greater length and stiffness to the tail-feathers. 
In a bird shot about two months later, in mid-November, the tips had disappeared, leaving 2 to $5 \mathrm{~mm}$. of strong, bare, projecting rhachis (Fig. 98, D). Even if there were no distinction of color or pattern between this plumage and that of the adult, the two could be told by a glance at the tail-feathers; those of the younger plumage showing unfinished, broken tips, while in the succeeding rectrices the shafts end in a delicately graduated point, clothed to the very tip with barbs (Fig. 98, E).

The Torrent Ducks are of interest in this respect, as showing that what in other members of the family is merely an evanescent physical connection between two series of feathers, has in this case been carried to a much greater extreme of specialization, probably of direct benefit to the species. 


\section{$2 \mathrm{BHL}$ Biodiversity Heritage Library}

Beebe, William and Crandall, Lee S. 1914. "Specialization of tail down in certain ducks." Zoologica : scientific contributions of the New York Zoological Society 1(13), 249-252. https://doi.org/10.5962/p.203798.

View This Item Online: $\underline{\text { https://www.biodiversitylibrary.org/item/97326 }}$

DOI: https://doi.org/10.5962/p.203798

Permalink: https://www.biodiversitylibrary.org/partpdf/203798

\section{Holding Institution}

Harvard University, Museum of Comparative Zoology, Ernst Mayr Library

\section{Sponsored by}

Harvard University, Museum of Comparative Zoology, Ernst Mayr Library

\section{Copyright \& Reuse}

Copyright Status: Public domain. The BHL considers that this work is no longer under copyright protection.

This document was created from content at the Biodiversity Heritage Library, the world's largest open access digital library for biodiversity literature and archives. Visit BHL at https://www.biodiversitylibrary.org. 